Original Paper

doi 10.15826/recon.2020.6.1.004

\title{
Smart city development projects in the Republic of Korea
}

\author{
Y.-S. Choi \\ State Administration of Information Technologies and Communications, Bishkek, Kyrgyzstan; \\ e-mail:ysangchoi@yahoo.com
}

\begin{abstract}
Research relevance. The article discusses the experience of South Korea in the sphere of smart city projects. The study's relevance is determined, on the one hand, by the role smart cities play in the creation of the new urban living space, in enhancement of urban economy and, on the other, by the need to analyze and systematize the best practices of smart city development. Research aim. The study describes the development of the 'smart city' concept in South Korea. Smart city is understood as a complex eco-system, which, on the one hand, comprises a range of technological and socio-economic processes and, on the other, involves such actors as government, corporations, research organizations and urban communities. Data and methodology. The study relies on methods of comparative and evolutionary analysis to analyze the concept of smart city and its structure by focusing on the case of South Korea, the world's renowned ICT leader. The study also provides cross-national comparisons of the experience of other developed Asian countries (Japan and China), which, like South Korea, are actively supporting building of smart cities on the state level. Results. The study describes the main stages in the development of the smart city concept in South Korea as well as the main types of smart city projects (pilot projects, research validation projects, and city restoration projects). The study identifies problems of planning, design and implementation of smart city projects and compares the relevant experience of South Korea, Japan and China. It is shown that although smart city projects in these countries were launched in approximately the same period, each of these countries has its own approach to smart cities and ways of their development. Conclusions. The key to Korea's success in smart city development lies in large-scale direct state support, public trust in the government and the application of an integrated approach to smart city development. At the current stage, smart city services not only provide enhanced comfort to city dwellers but also create more opportunities for their personal growth.
\end{abstract}

\section{KEYWORDS}

smart cities, South Korea, smart city pilots, infrastructure, urban ecosystem

\section{FOR CITATION}

Choi, Y.-S. (2020). Smart city development projects in the Republic of Korea. R-economy, 6(1), 40-49. doi: 10.15826/recon.2020.6.1.004

\section{Исследование опыта продвижения умных городов в Республике Корея}

\section{Я.С. Чой}

Государственное управление информационных технологий и связи, Бишкек, Кыргызстан; e-mail: ysangchoi@yahoo.com

\begin{abstract}
АННОТАЦИЯ
Актуальность. В статье рассматривается опыт Южной Кореи по реализации проектов «умных городов». Актуальность исследования определяется с одной стороны, значением умных городов для формирования нового пространства жизнедеятельности людей, повышения эффективности городской экономики; а с другой стороны, наличием значительного числа позитивных примеров внедрения проектов умных городов в Южной Корее. Цель исследования. Выявление особенностей внедрения концепции «умный город» в Южной Корее. При этом «умный город» рассматривается как сложная экосистема, которая включает в себя с одной стороны, технологические, и социально-экономические процессы, а с другой стороны такие факторы, как правительство, корпорации, научно-исследовательские организации и общественность. Данные и методы. Использованы методы сравнительного и эволюционного анализа подходов к формированию и реализации концепции «умного города» применительно к конкретной стране, Южной Корее. Выбор страны обусловлен лидерством (c) Choi, Y.-S., 2020
\end{abstract}

\section{КЛЮЧЕВЫЕ СЛОВА}

умные города, Южная Корея, пилотные проекты, инфраструктура, городская экосистема 
Южной Кореи в практическом воплощении проектов умных городов. В состав анализируемой совокупности при проведении кросс-национальных сравнений включены другие экономически развитые страны Азии (Япония и Китай), которые, как и Южная Корея, реализуют активную политику государственной поддержки умных городов. Результаты. Выделены основные этапы развития концепции «умного города» в Южной Коpeе, а также основные типы проектов «умного города», использующиеся в этой стране (пилотные проекты, проекты валидации НИОКР и проекты по восстановлению городов). Выделены проблемы, связанные с планированием, разработкой и реализацией проектов «умных городов». Выполнено сравнение опыта реализации концепции «умного города» в Южной Kopeе, в Китае и Японии. Показано, что, хотя проекты «умного города» в этих странах были запущены в один и тот же период, каждая из этих стран имеет свое понимание умного города и способов его развития. Выводы. Успех Южной Кореи в развитии концепции умного города обеспечен за счет высокого уровня прямой государственной поддержки и доверия населения к правительству, а также за счет комплексного подхода к внедрению. На современном этапе развития сервисы умного города обеспечивают не только более высокий уровень комфорта, но и возможности для саморазвития каждого жителя умного города.

\section{ДЛЯ ЦИТИРОВАНИЯ}

Choi, Y.-S. (2020). Smart city development projects in the Republic of Korea. R-economy, 6(1), 40-49. doi: 10.15826/recon.2020.6.1.004

\section{Introduction}

The development of information society led to the emergence of smart cities. Today the smart cities are the main component of the infrastructure of the future. For example, the McKinsey Company by 2020 predicts the emergence of 600 'smart cities', which will generate about two thirds of the world's GDP' ${ }^{1}$. The British standards institute describes the smart city as 'effective integration of physical, digital and human systems in an artificially created environment with the purpose to provide the steady, safe and comprehensive future for citizens'2.

The 'smart city' technology can be used to improve the management of city flows and ensure fast reaction to difficult tasks [1]. It should be emphasized that the term 'smart city' does not have a standard definition and is often used together with such synonymous terms as 'smart city' and 'digital city'. From the technical point of view, the 'smart city' represents a city information and telemetric network which gives to heads of different levels access to the uniform database and knowledge renewed in real time. Any project of a 'smart city' is a combination of several subsystems, which

${ }^{1}$ Henke, N., Bughin, J., Chui, M., Manyika, J., Saleh, T., Wiseman, B., Sethupathy, G. (2016). The age of analytics: competing in a data-driven world. Retrieved from: https://www. mckinsey.com/ /media/McKinsey/Business\%20Functions/ McKinsey\%20Analytics/Our\%20Insights/The\%20age\%20 of $\% 20$ analytics $\% 20$ Competing $\% 20 \mathrm{in} \% 20 \mathrm{a} \% 20$ data $\% 20$ driven\%20world/MGI-The-Age-of-Analytics-Full-report.ashx

${ }^{2}$ UNESCO (2019). Smart cities: shaping the society of 2030. Retrieved from: https://unesdoc.unesco.org/ark:/48223/ pf0000367762 include different functional parts (both individual and universal). In general, the concept of 'smart city' covers both the current needs of various city services and development prospects, as well as the demographic situation, ecology, and the requirements of organizations and residents.

A large body of contemporary research focuses on the phenomenon of smart cities, including the reports prepared by consulting companies such as McKinsey, PwC and European Data Portal, research groups and individual scholars such as L. Anthopoulos [2], I. Karabegovic [3], D. Keyson [4], S. Lee [5], D. Pal [6], V. Socheeva [7], J. Wagner [8] and others. Monardo describes 'Smart Strategies' in Boston as one of the most innovative cities in the United States and emphasizes the importance of proper 'territorialization' for the implementation of smart strategies and focuses on the fact that understanding the purpose of the territory and traditions of the local population is a key factor for the implementation of urban innovation [9]. Masucci shows that as smart cities form, inequalities between cities increase: the rich spaces of the new economy become smart, but most of the cities are far behind [10]. The purpose of this research consists in the identification of specifics of the implementation of the concept of a smart city in Korea. The study considers such topics as South Korean Government's smart cities policy, stages of smart city development, classification of smart services and the current status of Korea's smart city service; compares approaches to smart city development in South Korea, Japan and China. 


\section{Theoretical framework and methodology}

Our research draws from several groups of studies. First, there are studies discussing the role of the state in smart city projects. A. D'Auria, M. Tregua, and M. Vallejo-Martos show how the concept of smart cities influences the socio-economic conditions local communities are living in [11]. Angelidou, $M$.considers the factors that affect the choice of smart city models and the corresponding strategies of project development [12]. A. Meijer and M.P.R. Bolivar demonstrate the interconnection between state and local policies regarding smart city development [13]. There is also research focusing on the role of smart cities in the achievement of global and national development goals, for example, I. Turgel, L. Bozhko, E. Ulyanova, \& A. Khabdullin [14] consider the potential of smart city technologies in the light of global sustainable development goals. S. Praharaj, J.H. Han, and S. Hawken demonstrate the need to support smart city projects to stimulate innovation on the national level [15].

The second group of studies focus on the outcomes of smart city evolution in South Korea. The reason why South Korea attracts so much scholarly interest is this country's outstanding performance in ICT, the unique role played by the government in the process of smart city development (not only did the government initiate the search for new technological solutions but it also provided large scale support for such projects). In the last decades of the twentieth century, technological innovation was placed at the core of Korea's national idea. The vision of smart cities as a part of the national idea of economic leadership is discussed by J. Suh, H.C. Chen Derek, C. Choi, J. Choi, C. Kim and D. Lee, who conducted a comprehensive analysis of the state support of smart cities in South Korea, exploring the strengths and drawbacks of the state policy $[16 ; 17]$. In this respect, what seems particularly important is these authors' conclusion that at a certain stage, there has been a decline in the international competitiveness of the smart city projects in question. The studies of specific cases of Korean smart cities and their counterparts in other countries provide us with an understanding of the shortcomings of the state support system and their causes as well as the microlevel problems of smart cities' competitiveness (see, for example, J.H. Lee, M.G. Hancock and M.C. Hu [18]).
W. Yu and C. Xu [19] and H. Tamai [20] highlight the unique nature of South Korean cities in comparison with other Asian countries (China and Japan). South Korean experience is most often compared with that of China and Japan because these countries are high economic achievers and have similar visions of the role of state in national economy. In these countries, there is a substantial state-owned sector and the state acts as an economic agent in its own right to ensure the achievement of national development goals. Studies systematizing the most interesting cases of flagship smart city projects in South Korea describe the instruments used for smart city development. O. Benedikt [21], for example, describes the development of the smart city of Songdo. S.Y. Lee and H.J. Yoon [22] discuss the smart city project in Busan and Y. Kwon [23], in Sejong.

\section{Results and discussion}

\section{Five stages of smart city development in Korea}

Smart cities are important elements of the state industrial policy in South Korea ${ }^{3}$. On the one hand, a smart city ensures the infrastructural and innovative development of the territory. On the other hand, it is a promising investment project in which investors from other countries are ready to invest. To date, the Government 's position is to ensure the improvement of urban infrastructure and to allow citizens to determine the role of the new technologies in their lives.

The smart city has emerged as a new alternative solution to address urban problems such as urban deterioration, traffic congestion, energy shortages, environmental pollution, and crime. With the help of the smart city technology, it is possible to manage urban resources by collecting and analyzing urban information through ICT [24]. The smart city market is an innovative growth engine centered on energy, transportation and safety by utilizing ICT such as AI, Big Data, and $5 \mathrm{G}$. The smart city is one of the many convergence types based on ICT such as smart distribution, smart welfare, smart environment, and smart energy.

The five stages of smart city development in Korea are as follows:

Stage 1: infrastructure (existing U-city project). This stage combines the innovation and infra-

${ }^{3}$ Ubicom Programme. (2011). Ubiquitous City in Korea. Services and Enabling Technologies. Tekes-Finnode-Finpro. 
structure of a smart city. This provides the basis for the full-scale construction of smart cities [25]. Urban infrastructure plays a critical role in developing smart city development strategies. ICT infrastructure includes the construction of wired / wireless communication networks, e-government, the creation of an information society, the use of innovative technologies, such as open data.

Stage 2: vertical grid. It is a step to enhance the efficiency of urban operation by vertically linking and integrating individual sectors and services. Instead of integrating cities into one, a separate service-specific business approach is adopted. In the case of Korea, there is an increasing number of cases where an integrated city operation center is established and individual services are linked.

Stage 3: horizontal grid. Related functions and tasks share data and a platform to provide more sophisticated analysis and services. This stage is much more complicated than the second because governments must create convergence or inter-sector linking services.

Stage 4: city platform. It is a stage where the city works as one platform and the project is completed. By releasing the data-sharing problem into the technical architecture, data sharing within the city is transformed into a basic state, not a special one. The 'Algorithm and Service' layer of the Smart City Platform is developing dramatically with smooth data supply.

Stage 5: the city of the future. The most important thing in the technology of the urban platform is the function of 'artificial intelligence', which implements many types of data in real-time and increases the value of use and added value. At this stage, a smart city becomes a full-blown intellectual society. Just as the highest level of e-government in the past was 'government transformation', the next step in a smart city is moving to a new city. If a smart city will introduce intelligent technologies into the existing urban system, then at the next level, intelligent technologies can be used to create a new urban structure that does not currently exist.

\section{Steps of smart city development}

As the experience of South Korea shows, the process of planning, constructing an optimal customized smart city generally consists of four steps (see Table 1).

\section{Table 1}

Steps to build a smart city

\begin{tabular}{|l|l|l|l|}
\hline \multicolumn{1}{|c|}{ Steps } & \multicolumn{1}{|c|}{ Content } & \multicolumn{1}{c|}{ Role } & \multicolumn{1}{c|}{ Keypoints } \\
\hline $\begin{array}{l}\text { Step 1] } \\
\text { Analysis } \\
\text { of urban } \\
\text { situation }\end{array}$ & $\begin{array}{l}\text { Diagnose the } \\
\text { problems and } \\
\text { the situation } \\
\text { that the city } \\
\text { is facing }\end{array}$ & $\begin{array}{l}\text { Identifying ur- } \\
\text { ban problems } \\
\text { and analyzing } \\
\text { ways of smart } \\
\text { city promo- } \\
\text { tion }\end{array}$ & $\begin{array}{l}\text { Diagnosis of } \\
\text { urban problems } \\
\text { Urban system } \\
\text { research } \\
\text { ICT infrastruc- } \\
\text { ture diagnosis } \\
\text { Deriving core } \\
\text { service sector }\end{array}$ \\
\hline $\begin{array}{l}\text { Step 2] } \\
\text { Solutions }\end{array}$ & $\begin{array}{l}\text { Finding the } \\
\text { best smart } \\
\text { solutions for } \\
\text { urban prob- } \\
\text { lems }\end{array}$ & $\begin{array}{l}\text { Provide tech- } \\
\text { nical alterna- } \\
\text { tives for smart } \\
\text { city service } \\
\text { implementa- } \\
\text { tion }\end{array}$ & $\begin{array}{l}\text { Find solutions by } \\
\text { service } \\
\text { Building an } \\
\text { architecture } \\
\text { Basic structure } \\
\text { concept }\end{array}$ \\
\hline $\begin{array}{l}\text { Step 3] } \\
\text { System } \\
\text { design }\end{array}$ & $\begin{array}{l}\text { Designing } \\
\text { the system of } \\
\text { the smart city }\end{array}$ & $\begin{array}{l}\text { Design spe- } \\
\text { cific systems } \\
\text { based on } \\
\text { architecture }\end{array}$ & $\begin{array}{l}\text { Center system } \\
\text { design } \\
\text { Field system } \\
\text { design } \\
\text { Communication } \\
\text { system design }\end{array}$ \\
\hline $\begin{array}{l}\text { [Step 4] } \\
\text { Business } \\
\text { promo- } \\
\text { tion }\end{array}$ & $\begin{array}{l}\text { Promotion } \\
\text { of smart city } \\
\text { business } \\
\text { through } \\
\text { validation of } \\
\text { business }\end{array}$ & $\begin{array}{l}\text { Extend the } \\
\text { scope for } \\
\text { systematic } \\
\text { project man- } \\
\text { agement }\end{array}$ & $\begin{array}{l}\text { Cost / benefit } \\
\text { analysis } \\
\text { Pilot project } \\
\text { promotion } \\
\text { Implementation } \\
\text { of this project }\end{array}$ \\
\hline
\end{tabular}

Let us look at these steps in more detail.

Step 1: Analysis of urban situation

At this stage, urban problems are diagnosed through surveys and in-depth interviews with citizens [26]. For the government, it is necessary to ensure the maximum transparency of this process to stimulate citizen cooperation [27].

The smart city types are divided into an old urban type and new urban type. The old urban type refers to a city that has been providing smart city related services gradually for at least 10 years, and it is a city that has received favorable evaluations from the users [28]. The services already existing in 'old' smart cities usually include intelligent traffic and security systems. The new urban type is characterized by services and systems built in a short period of time by investing in urban development profit. The old city takes a long time to regulate the operation and maintenance of the system. In the case of the old city type, it is necessary to construct a system (construction design) based on the existing system. It is also necessary to conduct a thorough investigation of the existing systems to promote a new level of smart city.

As for smart city services, ICT plays a pivotal role as a means of implementing services to solve urban problems. The level of ICT infrastructure in the city is largely divided into supply and demand 
levels, which requires close examination. The supply dimension is divided into infrastructure diagnosis, which evaluates the development status of the ICT industry and network topology, and service diagnosis, which evaluates communication services such as Internet access and communication speed. The demand dimension is divided into acceptance diagnosis, which tests whether information service is available at a low cost, and content diagnosis, which evaluates the content development level using various applications.

Finally, it is necessary to identify the type of the future smart city's service sector and the most pressing urban issues; set priorities; and devise the basic policy directions of the government.

\section{Step 2: Solutions}

Based on the connectivity, cost-benefit and feasibility of the existing services and possible solutions, it is necessary to devise a unique solution for each smart city [29]. This process comprises prioritizing the core service areas, search for the possible options and choose the best solutions for each smart service.

The smart city architecture has four types: center system; field system; vehicle system; and personal portable system. The center system is an information platform where various real-time data such as traffic, crime prevention, disaster prevention, and water supply and drainage collected in the city are concentrated. The field system collects various situations occurring in the city by using advanced information gathering technology such as detectors, centers, and IoT, and it is a variety of devices such as CCTV and sensors. The vehicle system is installed inside a moving vehicle in the city to grasp the traffic situation and transmit it to the center in real time. The personal portable system utilizes the functions of smartphone software and hardware to induce citizen participation in urban administration without time and space limitations.

\section{Step 3. System design}

The center of all city information in the design of a smart city system is very important. It is a platform for combining information flows of the city [30]. In the case of the new city type, there is no problem because it is a new design, but in the case of the old city type, it is essential to integrate various information centers that have already been constructed physically and systematically.

A smart city field system design is important to find effective ways to build on-site equipment. Various sensors, CCTV, emergency bell, roadside communication equipment, license plate detector, etc. are required to collect various kinds of information according to service characteristics. It is desirable to plan multi-purpose structures in advance and systematically install them in order to efficiently build on-site systems. In order to build an effective smart city, it is essential to establish a self-dedicated optical communication network.

\section{Step 4. Business promotion}

In order to prove the feasibility of a smart city, it is important to calculate and compare the costs and benefits. Costs and benefits are important to calculate and compare to assess the feasibility of creating a smart city. It is especially important to evaluate the services provided by the public sector. Most services lack qualitative methodology because they have many qualitative benefits such as convenience enhancement, information provision, and satisfaction improvement. A preliminary feasibility study for a public project should include a calculation of the effect of reducing costs, the effect of reducing pollution, the effect of reducing the cost of accidents, and a methodology for calculating time savings as part of the implementation of smart city technologies.

For the step-by-step construction of a smart city, it is necessary to verify the feasibility of the project by promoting the pilot project as the first priority [31]. Pilot projects are an essential process to test the applicability of relevant technologies and to test local adaptability. It is a very important step to diagnose the effect of providing smart city service in advance.

Project management involving design planning, schedule management and supervision, pre-evaluation and post-evaluation is important. The business effect can be maximized by expanding the scope of smart city construction.

\section{Smart services in Korea: types and classification}

Inhabitants of smart cities in South Korea enjoy access to a large number of smart services. Smart services in all their diversity can be divided into 7 key functional areas: mobility healthcare, education, energy/environment, governance, culture and shopping, jobs and infrastructure (see Table 2). What should be emphasized is the comprehensive nature of smart services in the sense that they seek to encompass all aspects of contemporary urban life. In other words, the development of smart services is primarily oriented towards meeting the needs of in- 
dividual consumers. It should be noted that the Korean concept of smart services is associated with meeting such higher-order human needs as culture and education. Smart services, including those in the sphere of social entrepreneurship, are expected to facilitate the satisfaction of human needs. The functions of smart cities' services in Korea go far beyond the range of customary services for the improvement of mobility, energy efficiency and infrastructure.
Overall, there are 80 smart city services in South Korea. In fact, the experience of this country shows that smart city services not only create new opportunities to provide people with services of a better quality but also the opportunities for personal growth. Such understanding of smart cities is, however, just a starting point for further development in this sphere. The ultimate goal of these projects is to help city dwellers achieve their personal development goals.

Table 2

Smart Service in Korea

\begin{tabular}{|c|c|c|}
\hline Classification & $3^{\text {rd }}$ party services & City Operates \\
\hline Mobility & $\begin{array}{l}\text { Future vehicle test bed } \\
\text { Autonomous driving } \\
\text { Drone courier } \\
\text { Drones management and tailor } \\
\text { Shared vehicle service } \\
\text { Manage shared bikes } \\
\text { Smart crosswalk }\end{array}$ & $\begin{array}{l}\text { Logistics robot } \\
\text { C-ITS } \\
\text { Signal control for emergency vehicles } \\
\text { Autonomous Infrastructure Management } \\
\text { Local base logistics } \\
\text { Smart parking management } \\
\text { Smart streetlight } \\
\text { Smart Bus Shelter Management } \\
\text { BRT control service }\end{array}$ \\
\hline Health care & $\begin{array}{l}\text { Emergency drones } \\
\text { Unmanned Patrol } \\
\text { On-demand automatic shuttle } \\
\text { Robot assistant } \\
\text { Power wear wearable } \\
\text { Telemedicine Service } \\
\text { Real-time monitoring of resident health }\end{array}$ & $\begin{array}{l}\text { Intelligent Crime Prevention System } \\
\text { Electronic prescription (Blockchain) } \\
\text { Urban smart farm } \\
\text { Real-time disease analysis } \\
\text { Disease prediction } \\
\text { Disease map } \\
\text { Exercise compensation service }\end{array}$ \\
\hline Education & $\begin{array}{l}\text { Educational environment provision by } \\
\text { brain development cycle } \\
\text { On-line training space } \\
\text { Smart Classroom } \\
\text { International Baccalaureate }\end{array}$ & $\begin{array}{l}\text { Educational cloud rental } \\
\text { Ecology } \\
\text { Online Library }\end{array}$ \\
\hline $\begin{array}{l}\text { Energy / Environ- } \\
\text { ment }\end{array}$ & $\begin{array}{l}\text { Energy exchange (vehicles, building) } \\
\text { Smart AMI } \\
\text { Electric vehicle charging infrastructure } \\
\text { Solar Power (Solar) } \\
\text { Fuel cell vehicle spread } \\
\text { Smart leak detection } \\
\text { Smart water quality management } \\
\text { BIM / BEMS }\end{array}$ & $\begin{array}{l}\text { Independent Energy Management } \\
\text { Power Exchange (Urban DER: Distributed Energy Resources) } \\
\text { ESS management } \\
\text { Garbage transport robot control } \\
\text { Road cleaning robot control } \\
\text { Fine dust monitoring } \\
\text { Drone control for air quality measurement } \\
\text { Smart protection } \\
\text { Underground Community Management }\end{array}$ \\
\hline Governance & $\begin{array}{l}\text { Mobile space rental } \\
\text { Location tracking }\end{array}$ & $\begin{array}{l}\text { Digital Twin-AR (Augmented Reality) / VR } \\
\text { Integrated resident card (Blockchain) } \\
\text { City Tuning Infrastructure } \\
\text { Urban Design Analysis (Digital Twin) } \\
\text { Public chatbot } \\
\text { Smart Security } \\
\text { Integrated city operation control } \\
\text { GIS-based city control } \\
\text { Operate low-income infrastructures }\end{array}$ \\
\hline $\begin{array}{l}\text { Culture and Shop- } \\
\text { ping }\end{array}$ & $\begin{array}{l}\text { O2O service } \\
\text { Famers Market (flea market) } \\
\text { Culture / Shopping Street } \\
\text { Smart Performance Platform } \\
\text { Smart payment system }\end{array}$ & $\begin{array}{l}\text { Local Currency Service (Blockchain) } \\
\text { Smart signage } \\
\text { Social enterprise - employment for the disabled }\end{array}$ \\
\hline $\begin{array}{l}\text { Job and infrastru- } \\
\text { ture }\end{array}$ & $\begin{array}{l}\text { Incubation Service } \\
\text { Innovation Jim } \\
\text { Silver courier } \\
\text { Single bike delivery }\end{array}$ & $\begin{array}{l}\text { Data Marketplace (Living Lab) } \\
\text { Hacker ton }\end{array}$ \\
\hline
\end{tabular}




\section{Current status of Korea's smart city services}

There are three types of smart cities in Korea: pilot projects, $R \& D$ validation projects, and urban regeneration projects. Let us look at their characteristics in more detail.

\section{Pilot projects}

These cities were selected in 2018 from a total of 39 candidate cities. In the two pilot cities (Sejong and Busan), plots of 2-3 square kilometers were selected for subsequent development based on the calculated time and costs. Sejong City (officially known as Sejong Special Autonomous City) is the central administrative city of Korea, located $150 \mathrm{~km}$ south of Seoul, while Busan is located in the southeastern part of the country, $500 \mathrm{~km}$ from Seoul.

The Smart City Project in Sejong, located in a northeast residential area, covers $2.7 \mathrm{~km}^{2}$ and upon completion will have a population of 23,000 residents living in 9,000 households. The Busan Smart City Project, located in its western Gangseo district, will be called Eco-Delta City (EDC). The future Eco Delta City will be based on the area of $2.2 \mathrm{~km}^{2}$, including a part of the Nakdong River and its tributaries.

Some project components will be distributed in adjacent areas, bringing the total project size to $11.8 \mathrm{~km}^{2}$. The development will be led by two state-owned corporations, LH Corporation in Sejong and K-Water in Busan. LH Corporation, officially the Korea Land and Housing Corporation, is engaged in public housing and land administration. K-Water has expanded from managing water supply and resources to developing industrial complexes and clean energy projects.

\section{$R \& D$ validation projects}

This type of smart cities includes the cities of Daegu and Siheung. Siheung is a satellite city of Seoul. These cities were chosen as test sites or 'living laboratories' for the Korean smart city model in 2018. Urban development of this type of cities includes data collection, storage and sharing on an integrated city-wide platform.

The sites will be operational for five years until the end of 2022. Research in Daegu will focus on intellectual mobility, crime prevention and resilience to natural disasters and disasters. The projects inSiheung will focus on the environment, welfare and energy.

\section{Urban regeneration projects}

These smart cities are urban restoration projects aimed at reviving old urban areas and dealing with such problems as the lack of parking lots and potential security concerns through the use of data connectivity rather than large-scale redevelopment. These are projects of a small and thematic nature. Since February, 2019, these cities have included Daejeon, Gimhae, and Bucheon. The theme for Daejeon's development is 'The New Science City'. The project aims to demonstrate popular research and development, as there are many corporate and public research centers in the city. Bucheon will focus on using big data analytics to monitor and reduce air pollution across the city, and Gimhae will invest in AR and VR attractions for its historic sites.

The experience of South Korea is interesting to compare with that of its counterparts - China and Japan. In both countries, the process started in 2010. In China, the smart city development is a part of the $12^{\text {th }}$ Five-Year Plan. The first city to publish a municipal smart city development plan was Ningbo city in Zhejiang Province. In 2012, 6 pilot city projects were launched: in Beijing, Shenzhen, Shanghai, Hangzhou, Guangzhou, and Xiong'an. As for Japan, the four pilot projects were located in Keihanna, Kitakyushu, Toyota City and Yokohama. Starting from 2012, the Japanese government also chose several municipalities in Fukushima, Miyagi and Iwate prefectures for smart city projects in order to accelerate the urban and economic reconstruction of these areas.

In China, the development of a smart city is based on a centralized model with an emphasis on streamlining and enhancement of the efficiency of urban systems, especially regarding municipal government and public services. In Japan, the model is also centralized and focuses on fostering energy security and efficiency, local socio-economic development and enhancement of regional and global competition. The priority areas of smart city development in China include smart transport; smart water, smart energy and smart healthcare, while in Japan the focus is mainly on the reform of the electricity sector, introduction of the advanced metering structure (AMI), energy management system (EMS) and intelligent transport systems (ITS). In China, the process of building smart cities is managed by the Ministry of Housing and Urban-Rural Development (MOHURD); in Japan, it is the Ministry of Finance that is in charge of the reform.

While in Japan there are two types of smart city projects - those initiated by the private sector and initiated by LGs, in China, behind this process is 
the coalition of the public and private sector, authorities working together with large companies such as Huawei, Baidu, Alibaba, Tencent and so on.

It should be noted that the Chinese understanding of smart cities is technology-centric based upon cutting-edge information technologies such as IoT, big data, 5G, AI, and cloud computing. Smart city policies and initiatives in China focus mostly on the goals of enhancing the efficiency and effectiveness of economic development and urban management. In Japan, smart cities are highly specialized projects. Citizens do not take an active part in these projects. Although universities and $R \& D$ institutions are often mentioned in these projects and planning schemes, with the exception of Keihanna, they are not active players in this field and have but a limited influence on smart city projects.

Thus, smart cities in China, Japan and South Korea are generally focused on the introduction of advanced technologies. Cities in Japan are more focused on energy-saving technologies while China uses an integrated approach to smart cities as the government is building a system of interaction between the state, population and business. In Korea, a national strategic development project was launched - u-City (the ubiquitous computer city), whose goal is to improve the quality of life in cities through the ubiquitous ICT services supported by both the public and private sectors. The goal of u-City was to integrate advanced ICTbased infrastructures and ubiquitous information services into urban space to provide residents with a high quality of life, including safety, wealth, convenience and comfortable urban environment. Song-do City in Korea can be considered one of the most advanced Digital City projects in Asia.

\section{Conclusion}

Globalization, development of new technologies and related factors inevitably lead the cities to cardinal transformation. Thus, problems of cities turn into sources of new opportunities and their development involves innovative methods of management and new flexible strategies of development. Hidden sources of potential growth can be identified in multidisciplinary research. It is necessary to use progressive policy tools simultaneously at the conceptual, disciplinary and practical levels. In this case, it is important to train city managers in specially designed programs, partnerships with research universities, the creation of their own departments for urban development research, etc. Scenarios of the future of the cities gradual decline or total energies of the city with a new quality of life depend on the existence or lack of similar factors.

Smart city is a complex concept, which implies an interaction of all factors of urban environment and innovative technologies. The smart city model improves the quality of life, decreases the crime rate, increases the efficiency of the use of resources, productivity, transparency of public administration and mobility, leads to the emergence of the e-government, provides better access to education and helps decrease the unemployment rate and the level of air pollution.

In general, the situation in South Korea demonstrates the success of the smart city. Comparison with other countries shows that Japanese smart cities are more focused on energysaving technologies while China uses an integrated approach to smart cities as the government is building a system of interaction between the state, population and business.

\section{References}

1. Choi, C. (2018). A Big Data-Based Approach for Understanding Smart City Initiatives of South Korea. Science and Technology Trends, 73-85.

2. Anthopoulos, L., \& Fitsilis, P. (2013). Using Classification and Roadmapping techniques for Smart City viability's realization. Electronic Journal of e-Government, 11(1), 326-336.

3. Karabegović, I. (2019). New Technologies, Development and Application II. Springer International Publishing. doi: 10.1007/978-3-030-18072-0.

4. Keyson, D., Guerra-Santin, O., \& Lockton, D. (Eds.) (2017). Living Labs: Design and Assessment of Sustainable Living. Springer International Publishing. doi: 10.1007/978-3-319-33527-8.

5. Lee, S.K., Kwon, H.R., Cho, H., Kim, J., \& Lee, D. (2016). International Case Studies of Smart Cities: Orlando, United States of America. Pangyo: Inter-American Development Bank. doi: 10.18235/0000408.

6. Pal, D., Triyason, T., \& Padungweang, P. (2018). Big Data in Smart-Cities: Current Research and Challenges. Indonesian Journal of Electrical Engineering and Informatics (IJEEI), 6(4), 351-360. doi: 10.11591 /ijeei.v6i4.543. 
7. Socheeva, V. (2018). The role of the social laboratory (living lab Institution) and QuadrupleHelix model in the successful transition to a closed-loop economy (circular economy). Mezhdunarodnyi zhurnal gumanitarnykh I estestvennykh NAUK = International Journal of Humanities and Natural Sciences, 5-2, 199-201. (In Russ.) Retrieved from: https://elibrary.ru/item.asp?id=35144246\&.

8. Wagner, J., \& Watch, D. (2017). Innovation Spaces: The New Design of Work. Washington: The brookings institution.

9. Monardo, B. (2019) Innovation Districts as Turbines of Smart Strategy Policies in US and EU. Boston and Barcelona Experience. In: Calabrò F., Della Spina L., Bevilacqua C. (Eds.) New Metropolitan Perspectives. ISHT 2018. Smart Innovation, Systems and Technologies (pp. 322-335). Vol. 100. Springer. doi: 10.1007/978-3-319-92099-3 38.

10. Masucci, M., Pearsall H., \& Wiig A. (2019) The Smart City Conundrum for Social Justice: Youth Perspectives on Digital Technologies and Urban Transformations. Annals of the American Association of Geographers. 110(2), 476-484. doi: 10.1080/24694452.2019.1617101.

11. D’Auria, A., Tregua, M., \& Vallejo-Martos, M.C. (2018). Modern conceptions of cities as smart and sustainable and their commonalities. Sustainability, 10(8), 2642. doi: $10.3390 /$ su10082642.

12. Angelidou, M. (2014). Smart city policies: A spatial approach. Cities, 41, S3-S11. doi: 10.1016/j.cities.2014.06.007.

13. Meijer, A., \& Bolívar, M.P.R. (2016). Governing the smart city: a review of the literature on smart urban governance. International Review of Administrative Sciences, 82(2), 392-408. doi: 10.1177/0020852314564308.

14. Turgel, I., Bozhko, L., Ulyanova, E., \& Khabdullin, A. (2019). Implementation of the Smart City Technology for Environmental Protection Management of Cities: The Experience of Russia and Kazakhstan. Environmental and Climate Technologies, 23(2), 148-165. doi: 10.2478/rtuect-2019-0061.

15. Praharaj, S., Han, J.H., \& Hawken, S. (2018). Towards the right model of smart city governance in India. International Journal of Sustainable Development and Planning, 13(2), 171-186. doi: 10.2495/SDP-V13-N2-171-186.

16. Suh J., \& Chen D.H.C. (Eds.) (2007). Korea as a Knowledge Economy: Evolutionary Process and Lessons Learned. Washington D.C.: World Bank. Retrieved from: http://hdl.handle.net/10986/6755.

17. Choi, C., Choi, J., Kim, C. \& Lee, D. (2020). The Smart City Evolution in South Korea: Findings from Big Data Analytics. The Journal of Asian Finance, Economics and Business (JAFEB), 7(1), 301-311. doi: 10.13106/jafeb.2019.vol6.no4.179.

18. Lee, J.H., Hancock, M.G., \& Hu, M.C. (2014). Towards an effective framework for building smart cities: Lessons from Seoul and San Francisco. Technological Forecasting and Social Change, 89, 80-99. doi: 10.1016/j.techfore.2013.08.033.

19. Yu, W., \& Xu, C. (2018). Developing smart cities in China: An empirical analysis. International Journal of Public Administration in the Digital Age (IJPADA), 5(3), 76-91. doi: 10.4018/IJPADA.2018070106.

20. Tamai, H. (2014). Fujitsu's approach to smart cities. Fujitsu Scientific \& Technical Journal, 50(2), 3-10. Retrieved from: https://www.fujitsu.com/global/documents/about/resources/publications/fstj/archives/vol50-2/paper01.pdf.

21. Benedikt, O. (2016). The valuable citizens of smart cities: The case of Songdo City. Graduate Journal of Social Science, 12(1), 17-36. Retrieved from: http://www.gjss.org/sites/default/files/issues/ chapters/papers/GJSS\%20Vol\%2012-2\%201\%20Benedikt_0.pdf.

22. Lee, S.Y., \& Yoon, H.J. (2016). A Study on the Administrative Spatial Informatization and Ubiquitous Smart City: Focus on Busan Centum City. The Journal of the Korea Institute of Electronic Communication Sciences, 11(4), 351-364. doi: 10.13067/JKIECS.2016.11.4.351.

23. Kwon, Y. (2015). Sejong Si (City): are TOD and TND models effective in planning Korea's new capital? Cities, 42, 242-257. doi: 10.1016/j.cities.2014.10.010.

24. Dinh, D. (2018). ICT Enabling Technologies for Smart Cities. In $20^{\text {th }}$ International Conference on Advanced Communication Technology (IEEE-ICACT), 11-14 Feb. 2018. doi: $\underline{10.23919 /}$ icact.2018.8323849.

25. Serreli, S. (Ed.) (2013). City Project and Public Space. Springer Netherlands. doi: $\underline{10.1007 / 978-94-007-6037-0 .}$. 
26. Mortensen, J., Sweeting, D., Thakre, M., \& Ray, M. (2017). Urban Situation Analysis: Guide and Toolkit. Save the Children. Retrieved from: https://resourcecentre.savethechildren.net/library/ urban-situation-analysis-guide-and-toolkit.

27. Jadach-Sepioło, A., \& Muszyńska-Jeleszyńska, D. (2016). Analysis of the current situation of post-industrial sites in urban areas of three functional zones: Capital City of Warsaw, the City of Plock and the City of Radom together with the city of Pionki. Vienna: Interreg CENTRAL EUROPE.

28. Alqadad, A., Shahrourbc, I., \& Sukika, A. (2017). Smart system for safe and optimal soil investigation in urban areas. Underground Space, 2(4), 220-226. doi: 10.1016/j.undsp.2017.10.003.

29. Rodriguez, J.A., Fernandez, F.J., \& Arboleya, P. (2018). Study of the Architecture of a Smart City. Proceedings, 2(23), 1485. doi: 10.3390/proceedings2231485.

30. Nam, T., \& Pardo , T. (2011). Conceptualizing smart city with dimensions of technology, people, and institutions. In Proceedings of the $12^{\text {th }}$ Annual International Digital Government Research Conference: Digital Government Innovation in Challenging Times, June 2011 (pp. 282-291). doi: 10.1145/2037556.2037602.

31. Aijaz, R. (2017). Smart Cities Movement in BRICS. London: Global Policy and Observer Research Foundation. Retrieved from: http://nkibrics.ru/system/asset publications/data/594a/3 1a3/6272/6948/8295/0000/original/Smart-Cities.pdf?1498034595.

\section{Information about the author}

Young-Sang Choi - Consultant in Kyrgyzstan Information Technology \& Communication Committee (41 Umetalieva Str., Bishkek, 720010, Kyrgyzstan); e-mail: ysangchoi@yahoo.com

ARTICLE INFO: received October 12, 2019; accepted March 5, 2020

\section{Информация об авторе}

Чой Янг Санг - Консультант по политике в области ИКТ и электронному правительству, Государственное управление информационных технологий и связи (720010, Кыргызстан, г. Бишкек, ул. Уметалиева, 41); e-mail: ysangchoi@yahoo.com

ИНФОРМАЦИЯ О СТАТЬЕ: дата поступления 12 октября 2019 г.; дата принятия к печати 5 марта 2020 г. 